\title{
Some problems in Piketty: An internal critique
}

\author{
Alan Tapper \\ Curtin University*
}

\begin{abstract}
Thomas Piketty's evidence on wealth distribution trends in Capital in the TwentyFirst Century shows that - contra his own interpretation - there has been little rise in wealth inequality in Europe and America since the 1970s. This article relates that finding to the other principal trends in Piketty's analysis: the capital/national income ratio trend, the capital-labor split of total incomes and the income inequality trend. Given that wealth inequality is not rising markedly, what can we deduce about the putative causes that might be operating upstream? Only the capital-labor split looks like a plausible explanation of the wealth inequality trend.
\end{abstract}

Keywords : Capital/income ratio, capital-labor split, income inequality, Piketty, wealth inequality

JEL Classifications: D31

\section{Introduction}

Economic inequality is one of the major subjects of the moment and no contribution to that discussion has been more important than Thomas Piketty's Capital in the Twenty-First Century, an empirically rich, theoretically ambitious and absorbing take on long run trends in the distribution of wealth and income. He uses 'capital' as synonymous with 'wealth' (Piketty 2014a, p. 47). His view is that economic inequality should be measured not primarily by income but by wealth. His main thesis is that the long-run trend in modern capitalist economies is towards greater inequality of wealth. This trend was diverted in the period 1914 to 1970, but has resumed in recent decades and a divide has been emerging between the super-rich ('the top 1\%') and the rest of us. Much of the book is devoted to building an explanation of how modern economies generate this division. Thus, he is arguing on two fronts: one, to show that wealth inequality is rising; and two, to explain why it is rising. One cannot fail to be impressed by much of Piketty's evidence and his theoretical analysis in support of his explanation. But I find myself unconvinced that wealth inequality is in fact rising in the way that his theoretical analysis predicts, and in large part my lack of conviction is based on his own evidence. This article offers an internal critique of his argument, operating within the framework he assumes.

${ }^{*}$ Address for Correspondence: Curtin University, Kent Street, Bentley, WA, 6102, Australia. Email: alandtapper@gmail.com Alan Tapper is currently a Senior Research Fellow, John Curtin Institute of Public Policy. 
Piketty counterposes his argument against the claim by Simon Kuznets (Kuznets 1955) in the 1950s that economic inequality is trending generally downwards in modern economies. 'According to Kuznets's theory, income inequality would automatically decrease in advanced phases of capitalist development, regardless of economic policy choices or other differences between countries, until eventually it stabilized at an acceptable level' (Piketty 2014a, p.11). Piketty's contention is equally ambitious: advanced capitalist societies seem to be heading in the opposite direction, towards greater inequality. But whereas Kuznets couched his claim as one about income inequality, Piketty proposes that we focus on wealth inequality, making income inequality a subsidiary theme, one important mainly to the extent that it tends to lead to the entrenchment of wealth inequalities. It is a significant shift of emphasis. This discussion will keep the focus on Piketty's treatment of wealth. His real concern throughout Capital is the risk of a rise in wealth concentration that amounts to the formation of a social class of the super-rich - what he calls 'the emergence of a new patrimonial capitalism', which he understands as a self-reinforcing class that is potentially an oligarchy. Paul Krugman (Krugman 2014) described Capital as offering 'what amounts to a unified field theory of inequality, one that integrates economic growth, the distribution of income between capital and labor, and the distribution of wealth and income among individuals into a single frame'.

Not surprisingly perhaps, this 'unified field theory' has attracted an extensive range of thoughtful criticism. Some think that rising inequality is a minor matter if economic growth is raising the living standards of all. Some think that competitive capitalism is self-correcting, so that returns on capital will level off over time. Others see wealth as tending to be dispersed, through non-productive consumption and through inheritance and social mobility. Some regard increased inequality as an inevitable feature of globalization. What many of these criticisms have overlooked is the much simpler question of whether Piketty's evidence indeed supports his thesis. Here I simply focus on whether Piketty's evidence coheres in the way he thinks it does. My contention is that the components of his argument lack any such unity. My doubts start with Piketty's account of the trends on wealth inequality.

\section{Wealth inequality}

Piketty spends twelve chapters developing his analysis of a variety of inequality-related trends and their historical and economic explanation. Curiously though, it is not until Chapter 10 ("Inequality of capital ownership") that he presents his long-run trends on the distribution of wealth. The best visual summary of these trends is his Figure 10.6 (Piketty 2014a, p. 349), shown here. 
Figure 10.6. Wealth inequality: Europe and the U.S., 1810-2010

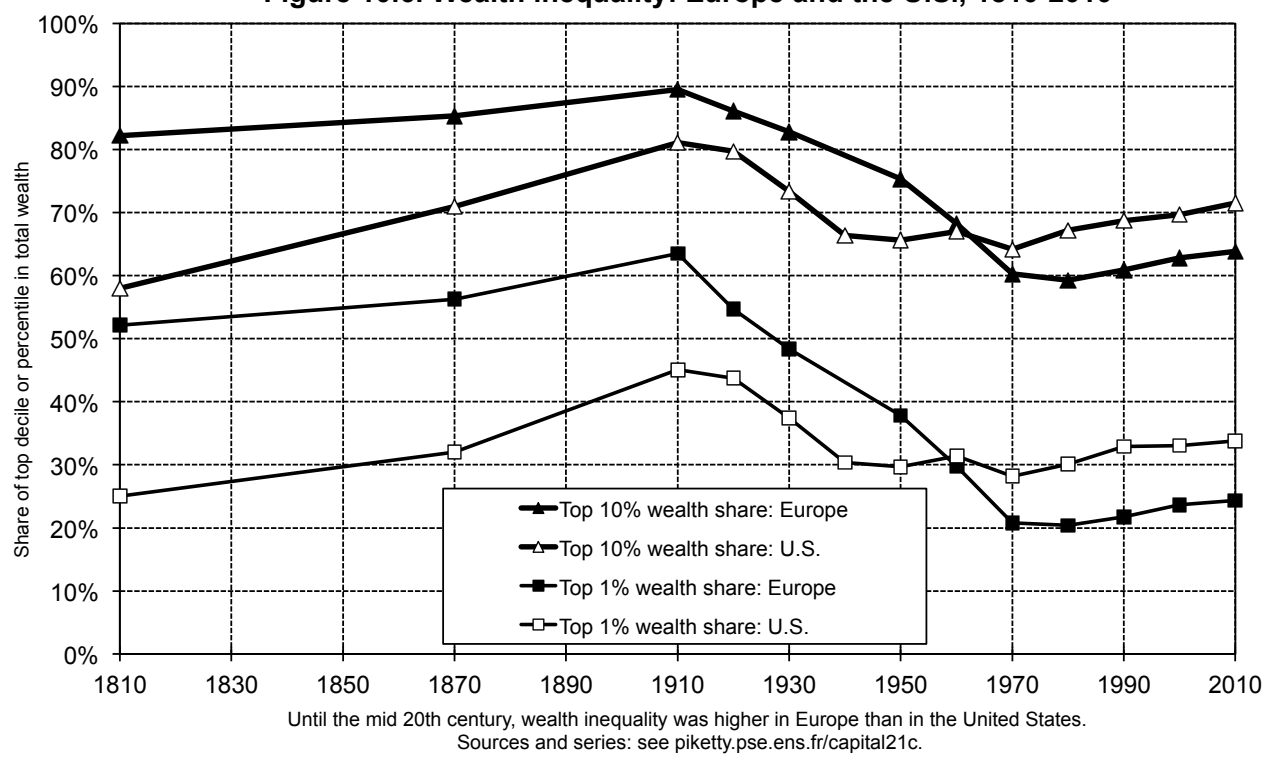

Here Piketty is contrasting 'European' (a composite of France, Britain and Sweden) and American trajectories. Wealth inequality was higher in 19th century Europe (so defined) than in America, but in the 20th century inequality fell more in Europe than it did in America. Those points are clear in Figure 10.6. But what has happened since 1970? Piketty merely notes that 'inequality of wealth began to rise again in 1970 - 1980' (Piketty 2014a, p. 372). He makes no appraisal of the magnitude of that rise. For anyone who has followed Piketty's overall argument, Figure 10.6 presents a surprising spectacle: it shows that in both north-western Europe and America wealth inequality is growing hardly at all. Top 10\% shares of total wealth rose in America from 66\% in 1940 to $71 \%$ in 2010 and in Europe from $60 \%$ in 1970 to $64 \%$ in 2010 . These are high levels of wealth concentration, but as multi-decadal trends they are slight. The same is true for the trend in the top 1\% shares: rising in the US from 30\% in 1940 to 34\% in 2010; in Europe rising from $21 \%$ in 1970 to $24 \%$ in 2010 . Table 1, based on Piketty's online database, shows the levels and trends in more detail. Across the four economies from 1970 to 2010 the top $10 \%$ share rose on average by $7.4 \%$ (about $1.5 \%$ per decade), while the top $1 \%$ share rose on average by $17.7 \%$ (about $4 \%$ per decade).

In a later discussion Piketty (2014c) says that in north-western Europe wealth inequality has 'increased moderately since the 1980s - 1990s', while in America 'in recent decades it rose more strongly than in Europe'. But Figure 10.6 shows 
almost no difference between the two, and the trends can hardly be called 'moderate'. They are rather underwhelming. By way of contrast, the rising trend in income inequality in the US and the UK is indisputably large (see Piketty 2014a, pp. 323-324, Figures 9.7 and 9.8; the latter is shown below on page 18).

Table 1

Concentration of wealth in Europe and the United States, 1970 - 2010

\begin{tabular}{lccccccccccc}
\hline & \multicolumn{2}{c}{ United } & \multicolumn{2}{c}{ Europe } & \multicolumn{2}{c}{ France } & \multicolumn{3}{c}{$\begin{array}{c}\text { United } \\
\text { Kingdom }\end{array}$} & \multicolumn{2}{c}{ Sweden } \\
& Top & Top & Top & Top & Top & Top & Top & Top & Top & Top \\
& $10 \%$ & $1 \%$ & $10 \%$ & $1 \%$ & $10 \%$ & $1 \%$ & $10 \%$ & $1 \%$ & $10 \%$ & $1 \%$ \\
\hline 1970 & 0.64 & 0.28 & 0.60 & 0.21 & 0.62 & 0.22 & 0.64 & 0.23 & 0.55 & 0.18 \\
1980 & 0.67 & 0.30 & 0.59 & 0.20 & 0.62 & 0.22 & 0.63 & 0.23 & 0.53 & 0.17 \\
1990 & 0.69 & 0.33 & 0.61 & 0.22 & 0.61 & 0.22 & 0.64 & 0.24 & 0.58 & 0.20 \\
2000 & 0.70 & 0.33 & 0.63 & 0.24 & 0.62 & 0.24 & 0.69 & 0.27 & 0.58 & 0.20 \\
2010 & 0.72 & 0.34 & 0.64 & 0.24 & 0.62 & 0.24 & 0.71 & 0.28 & 0.59 & 0.21 \\
\% Increase & & & & & & & & & & \\
1970-2010 & 11.4 & 19.9 & 6.00 & 17.4 & 0.60 & 10.0 & 10.0 & 23.9 & 7.4 & 17.0 \\
\% Increase & & & & & & & & & & \\
1980-2010 & 6.40 & 12.3 & 7.8 & 19.4 & 0.90 & 10.8 & 12.6 & 23.3 & 10.1 & 25.5 \\
\hline
\end{tabular}

Source: Based on Piketty (2014b), Online database

More striking than the trends is the level of wealth inequality that he shows in the United States, France, Britain and Sweden. In these four countries the top $10 \%$ of the distribution typically owns about $60 \%$ of total wealth, despite their very different histories and policy regimes. Piketty's method of argument - his wealth dynamics and trend-tracking - shed little light on that kind of fact. And that is a different topic.

\section{Economic theory}

The surprisingly weak trend in wealth inequality sent me back to the key points earlier in where a considerable rise seemed to be evident or at least imminent. Piketty distinguishes between the economic level of analysis (Part Two of the book) and the individual level (Part Three). The latter examines direct evidence of inequality trends in income and wealth, such as that shown in Figure 10.6. The former examines the economic drivers that influence inequality trends. I will start with his discussion of the economic drivers and then turn to the individual level evidence. 
I approach the question empirically. That is, I am not entering into Piketty's theoretical claims about the relationship between rates of return on capital and economic growth rates (his $r>g$ ). He posits two 'fundamental laws of capitalism': first, that the rate of return on capital $(r)$ is equivalent to the share of income from capital $(\alpha)$ divided by the capital/national income ratio $(\beta)(\alpha=r \beta)$; and secondly, that 'the higher the saving rate $[s]$ and the lower the growth rate $[g$, counting both demographic and economic growth] the higher the capital/income ratio' $(\beta=s / g)$ (Piketty 2014a, pp.52, 55, 166). 'Capital' is defined as 'the sum total of nonhuman assets that can be owned and exchanged on some market' (Piketty 2014a, p. 46); national income is defined as 'the sum of all income available to the residents of a given country in a given year, regardless of the legal classification of that income' (Piketty 2014a, p. 43).

Put all that aside: Piketty's theoretical analysis of wealth dynamics is a matter for economist theorists to evaluate. My focus is on the economic indicators that he thinks point towards rising inequality, given the operation of his postulated economic 'laws'. There are two main indicators: the capital/national income ratio $(\beta)$ and the capital-labor split $(\alpha)$. Of these two he thinks that the capital/income ratio is a better indicator, though not the one usually used.

\section{The capital / income ratio $(\beta)$}

Much of Piketty's argument rests on trends in the capital/income ratio; that is, the ratio between private capital holdings and national income tracked across time. This takes us to Piketty's argument in Chapter Five ('The capital/income ratio over the long run'). In Figure 5.3 (Piketty 2014a, p. 171; below) he shows the trend since 1970 of private capital as a share of national income for the eight richest modern economies. The composite picture seems clear enough: the capital/national income ratio has doubled in 40 years. Hence Piketty's section headline: 'Capital's comeback in rich countries since the 1970s'. In his view, the trend indicates 'the emergence of a new patrimonial capitalism' (Piketty 2014a, p. 173). It is hard not to read that phrase as suggesting the emergence of a new patrimonial capitalist class, a subset of the population largely closed to new entrants, though logically that need not follow: patrimonial capitalism may be flourishing while also becoming more dispersed demographically, as in the idea that welfare-state capitalism is evolving into a form of property-owning democracy. 
Figure 5.3. Private capital in rich countries, $1970-2010$

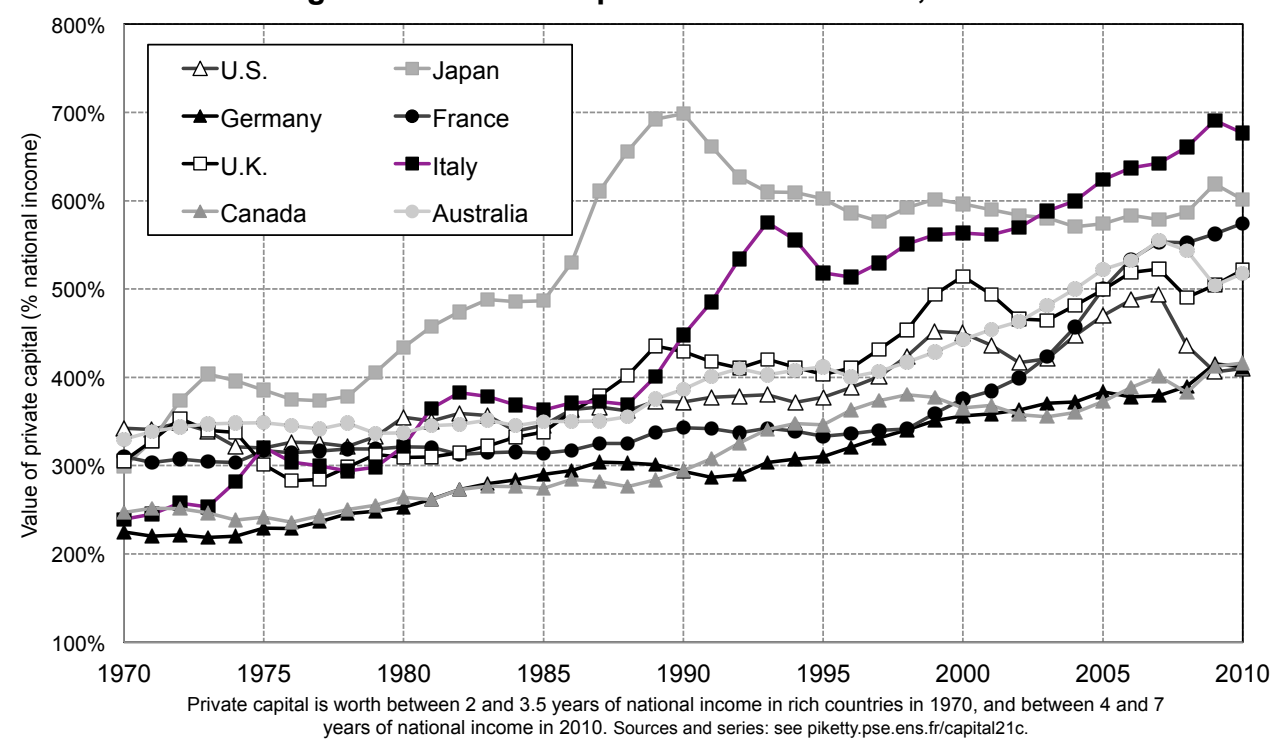

Figure 1

Capital / income ratio change, 1970 - 2010

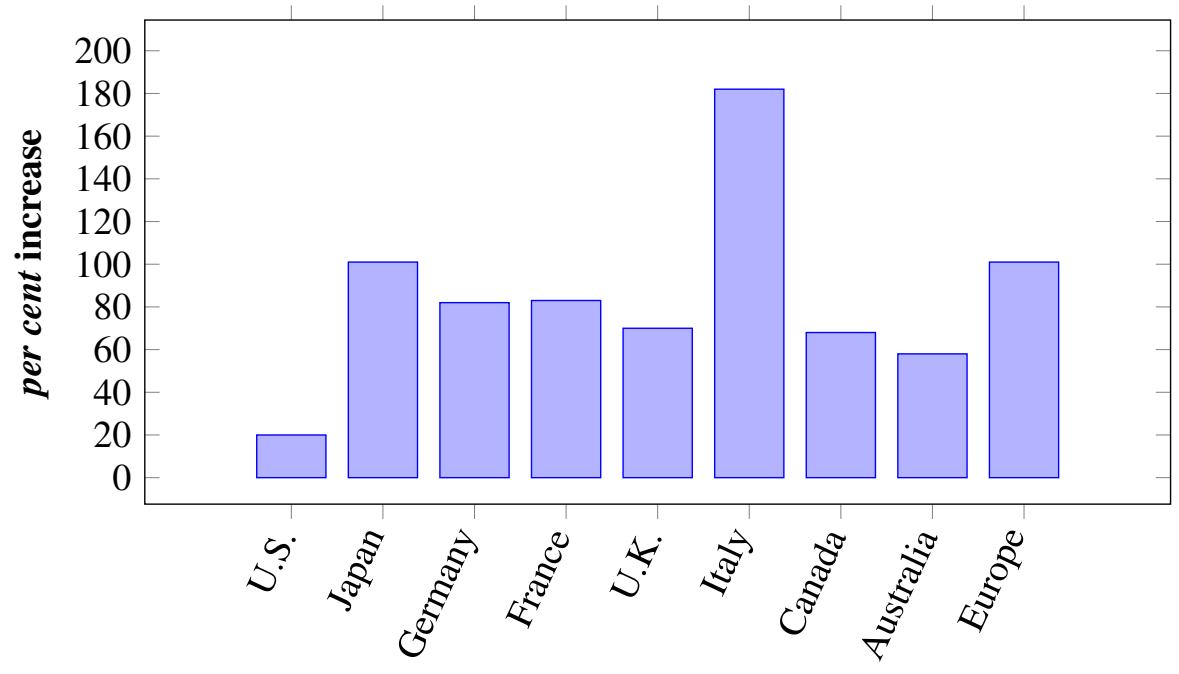

Source: Based on Piketty (2014b), Online database 
How far does Figure 5.3 really indicate a single general phenomenon? What happens if we compare the trends country-by-country? Using Piketty's own online database we get a curious result, as shown in Figure 1. This decomposition dispels any impression of uniformity. Piketty recognizes that 'the capital/income ratio is structurally higher in Europe and Japan than in the United States' (Piketty 2014a, p. 175), but he doesn't show just how different they are. The capital/income ratio has increased most in Europe (Germany, France, Britain, Italy) and Japan, and least in the United States, with Canada and Australia occupying a middling position. In Figure 1 the US increase is as low as one-fifth that of Europe (so defined) and Japan; it is one-quarter that of France and Germany.

However Figure 1 might be deceptive if the starting and finishing points are unrepresentative of the whole trend. To test for this we can show the trends for America, Europe and a composite of France and Britain (which we will need in order to make comparisons with Piketty's wealth inequality trend). Figure 2 shows these trends.

Figure 2

Capital / income ratio trends, 1970 to 2010

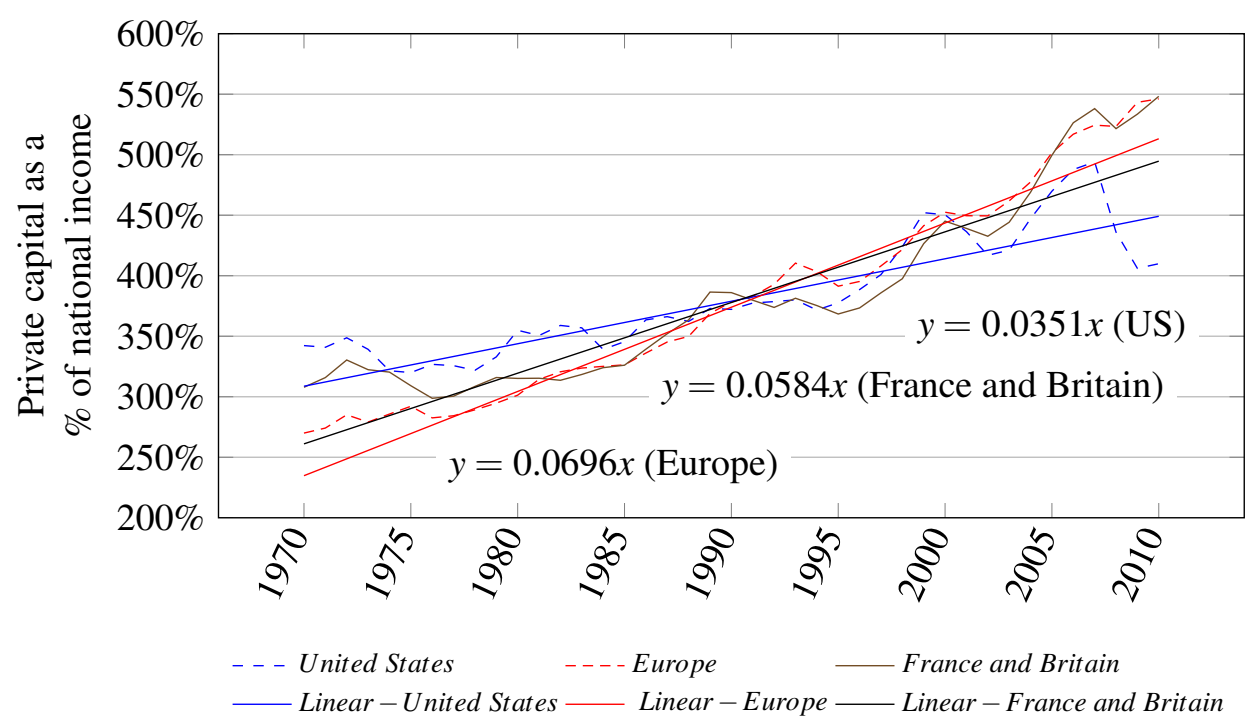

Source: Based on Piketty (2014b), Online database

Figure 2 shows that America is not as different from Europe or from France/Britain as Figure 1 suggested, and the reason is clear: until 2008 there was not much difference between them, but after 2008 America and Europe went in different directions, with private capital's share of national income crashing in the 
United States but continuing to rise in Europe. To minimize this distortion and to get a better guide to the trends linear trendlines are shown. These indicate that the trend for Europe is rising nearly twice as fast as that for America, while that for France/Britain is rising two-thirds faster than the American trend. Thus we still find strong differences between the two regions.

Why so different? It is not, Piketty thinks, because of economic growth rates, which he argues do not differ very much since 1970. But demographic growth rates and private savings rates, both of which vary considerably between rich countries, do explain the differences. 'If one now combines variations in growth rates with variations in savings rates, it is easy to explain why different countries accumulate very different quantities of capital, and why the capital/income ratio has risen sharply since 1970' (Piketty 2014a, p. 175). Let's accept this. (The figures in Table 5.1 (Piketty 2014a, p. 174) seem to support it.) But in that case what follows about wealth inequality trends? Surely it is that the larger the capital/income ratio, the greater the propensity towards wealth inequality. This takes us back to Figure 10.6. In that figure the trend in wealth inequality since 1970 is essentially the same for north-western Europe and America, a slight rise in both cases. But if Figure 5.3 is an indicator or precursor of wealth inequality trends, the trend for Europe should be rising far more sharply than that for America. Admittedly 'Europe' means something different in each case (France, Britain and Sweden in his Figure 10.6, France, Germany, Britain and Italy in Figures 1 and 2). But the point remains valid if we compare just France and Britain with the United States in both cases: after eliminating the Swedish component the two are still rising at about the same rate. Yet if Figure 5.3 is our guide to the forces driving wealth inequality then inequality should be rising far faster in France and Britain than in the United States. Piketty also tracks trends in the ratio between private capital and total disposable income for the same eight economies over the same period. He sees this as simply another way of measuring the capital/income ratio. The results are shown in his Figure 5.4 (Piketty 2014a, p. 181; below).

Applying the same decomposition procedure as in Figure 2, we get Figure 3. Here the contrast between America and Europe is even more pronounced than in Figure 1. In the United States the share of private capital has hardly changed, while it has doubled in Europe (defined as in Figures 1 and 2). Italy is again an outlier, but private capital shares have grown strongly also in France and Germany. Again, if Figure 5.4 is our guide then wealth inequality should be rising very much faster in France and Britain than in the United States, which is contrary to the findings of Piketty's Figure 10.6. 
Figure 5.4. Private capital measured in years of disposable income

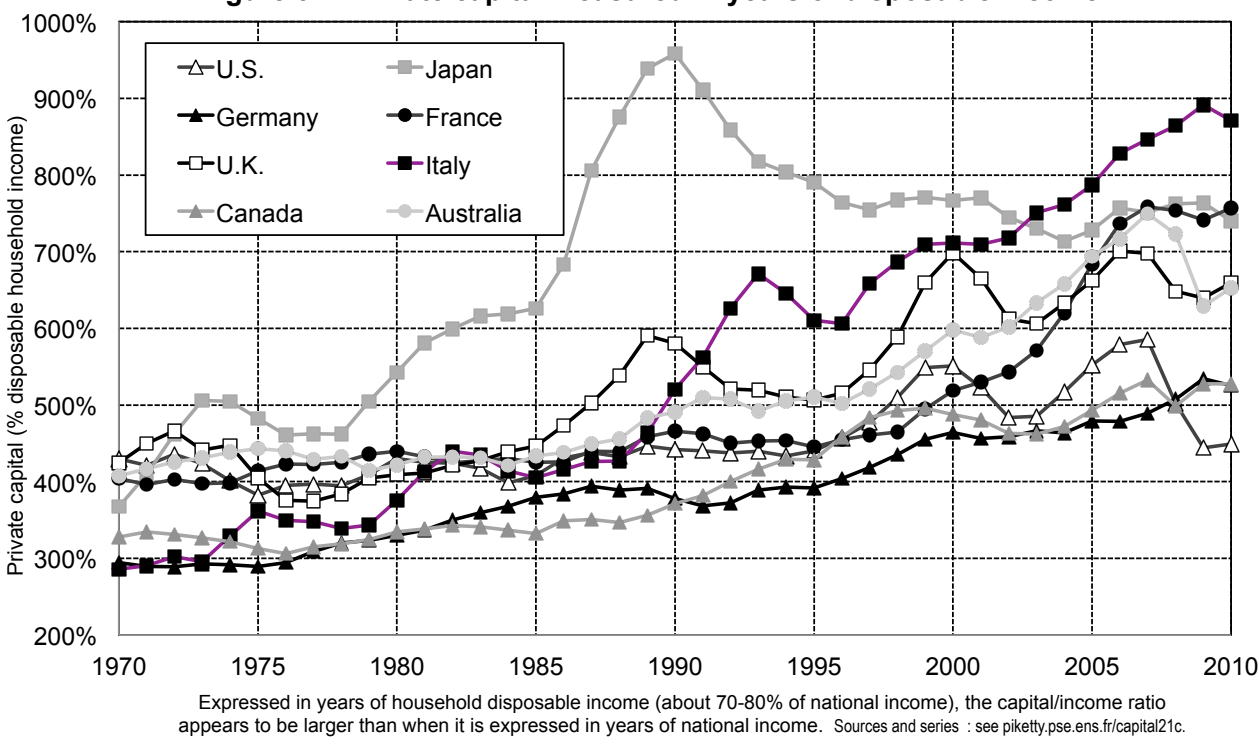

Figure 3

Private capital/disposable income ratio change, 1970 to 2010

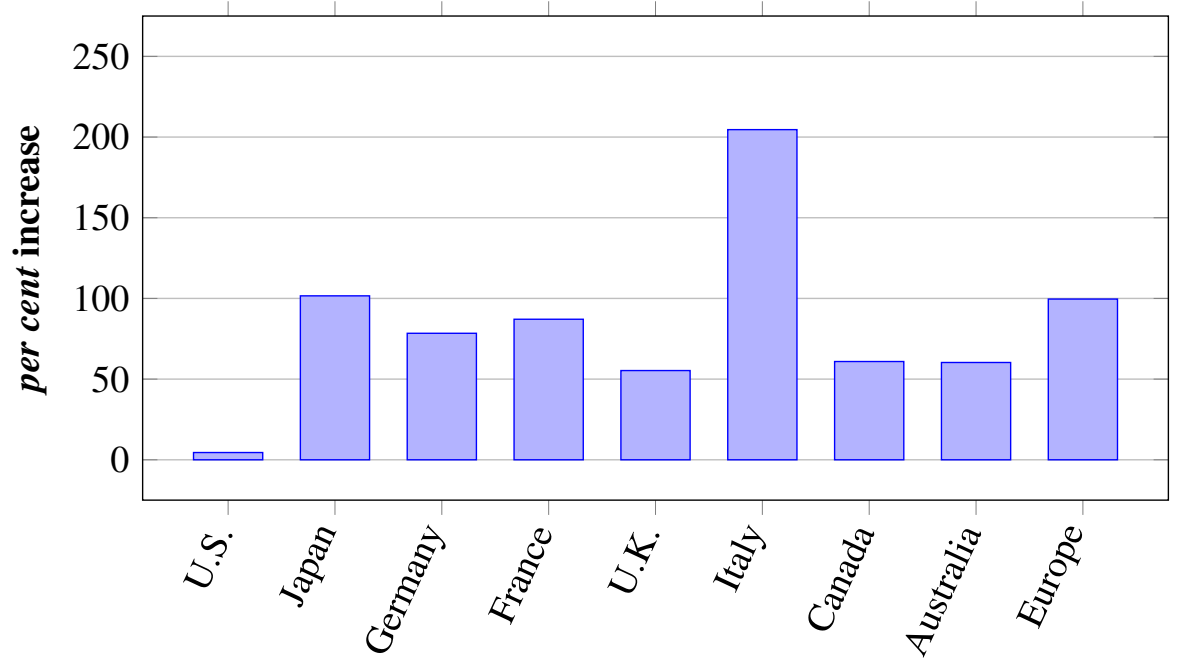

Source: Based on Piketty (2014b), Online database 
As before, we need to check for distortions resulting from the choice of starting and end points. Figure 4 provides the check. It shows that the radical difference between America and Europe in Figure 3 is exaggerated, but the difference is still large. The linear trendlines give a useful guide. The European and France/Britain trendlines are rising at more than twice the rate of the American trend and the divergence is most marked in the decade after 2000.

Figure 4

Private capital / disposable income ratio trends, 1970 to 2010

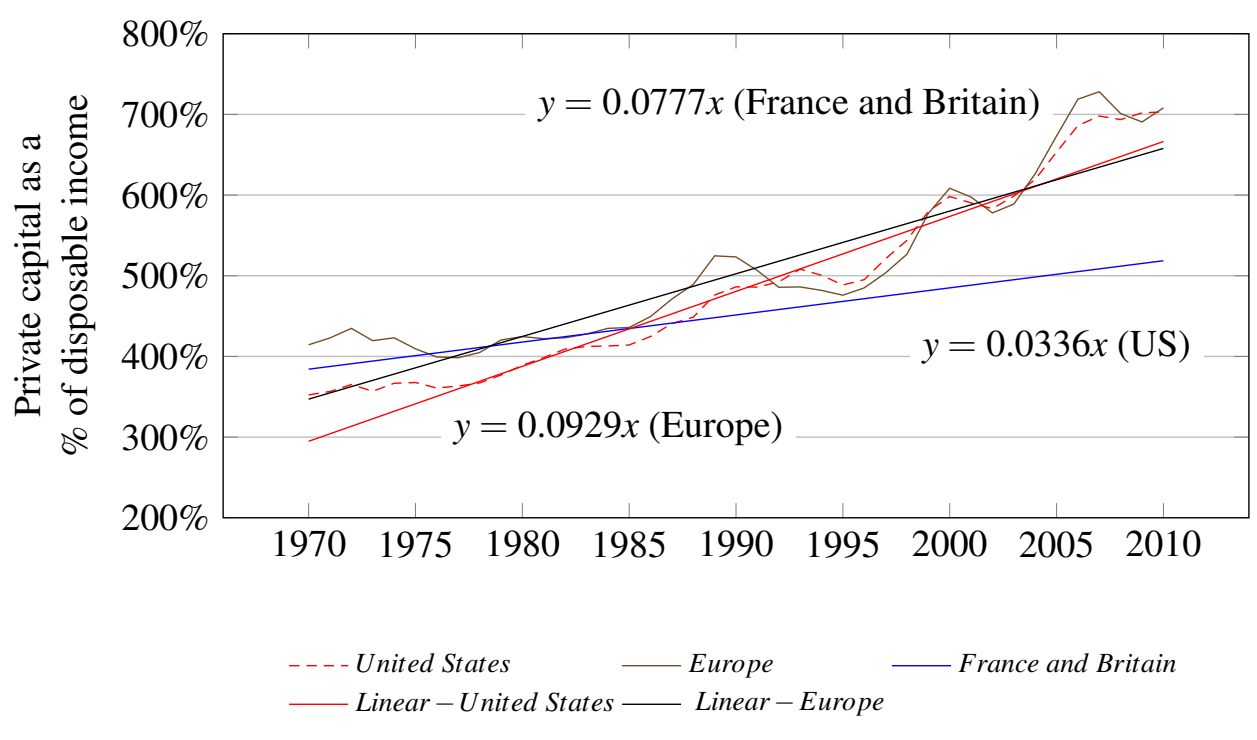

Source: Based on Piketty (2014b), Online database

\section{The capital-labor split $(\alpha)$}

This mismatch between the capital/income ratio trend and the wealth inequality trend is puzzling, but the picture becomes even more so if we turn to Chapter Six ('The capital-labor split in the twenty-first century'). The capital-labor split is the share of income from capital as a percentage of national income. Piketty presents this as another economic driver of inequality: the higher the capital share the higher wealth inequality is likely to be. As noted above, it is not his preferred indicator, so the capital share of income plays only a secondary role in his argument. It does however get some discussion in Chapter Six.

In his Figure 6.5 (below) Piketty shows a composite trend similar to that in Figure 5.3. It tracks the capital-labor split in the top eight economies from 1975 
to 2010 . The overall trend is roughly a $50 \%$ increase over 35 years. Piketty does not discuss the details of Figure 6.5, but as before we are led to wonder about the uniformity of the trend. Figure 5 (1970 - 2010; derived from Piketty's online database) shows the trends for each of the eight countries and for Europe (here comprising France, Germany, Britain and Italy) as a whole.

Figure 6.5. The capital share in rich countries, 1975-2010

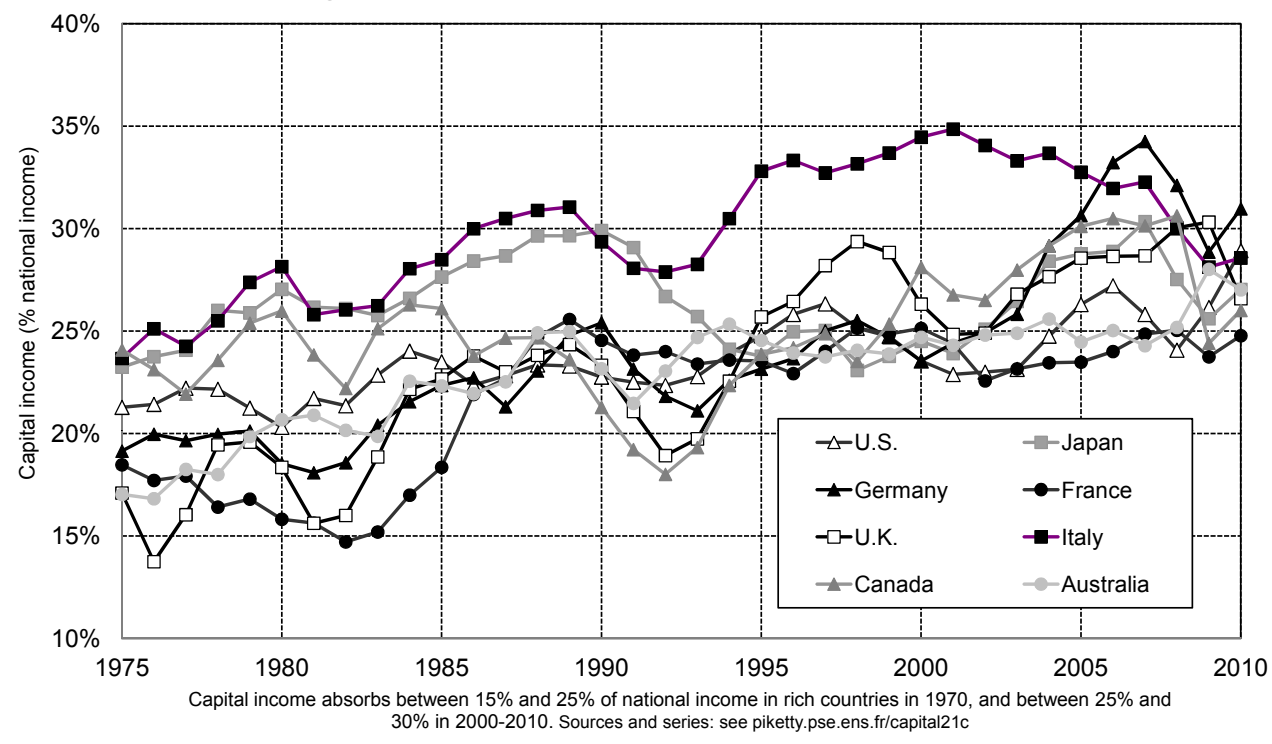

In Figure 5 there is no commonality between the European economies (so defined); Japan is an outlier; and the strongest trend is that for America (whereas the American trend was the weakest in Figures $1-4$ ). Focusing just on France, Britain and America, we see very little increase in France, a middling increase in Britain and the largest increase (nearly eight times that in France) in America. On this basis wealth inequality should be growing most in America and least in France, but this is not what we find in Piketty's Figure 10.6 or my Table 1, where wealth inequality is growing at a similar low rate in all three. 
Figure 5

Capital share trend, 1970 to 2010

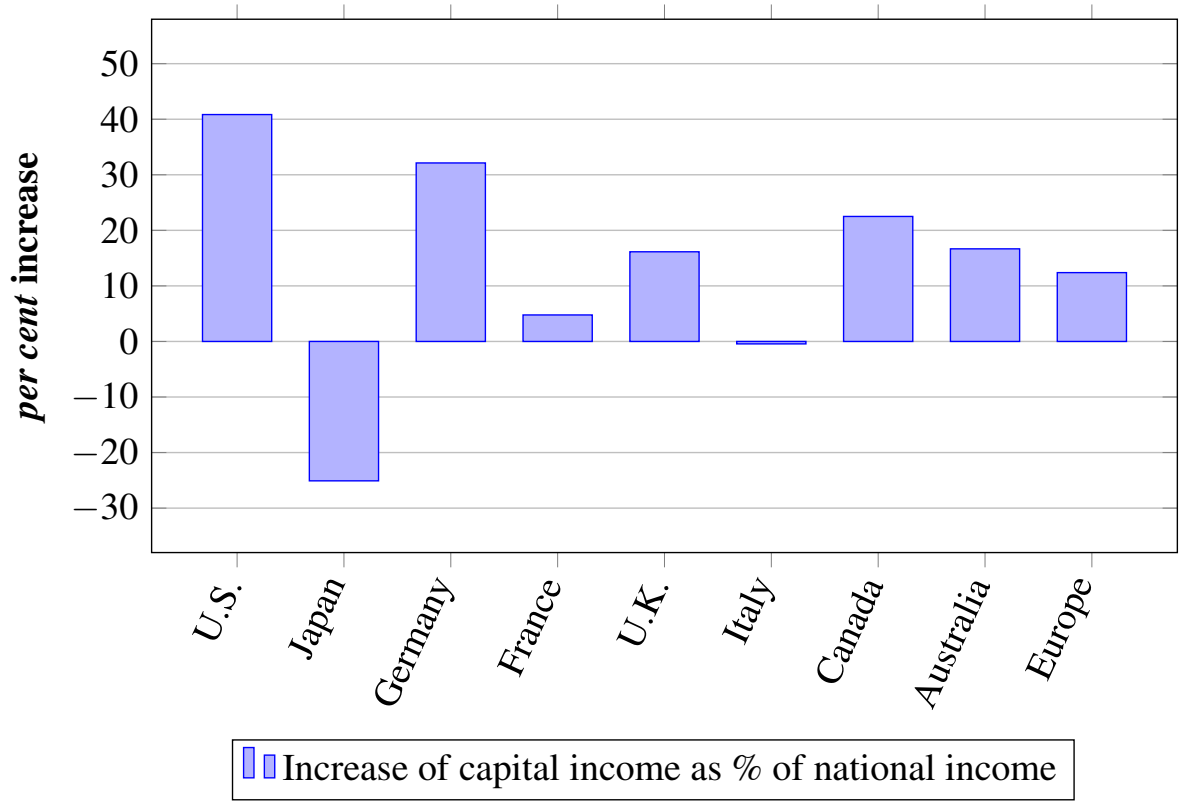

Source: Based on Piketty (2014b), Online database

Figure 6 compares the same trend in America and Europe (here comprising France, Germany, Britain and Italy) with in addition a trendline for France and Britain. In Figure 6 the American and European trends are broadly similar in the whole period but especially so after 1985 . When we reduce the comparison to that between America and France/Britain we see a marked divergence in the period 1975 to 1985 and convergence thereafter. Allowing for that period of divergence, the general picture is one of general similarity between America and Europe, whether broadly or narrowly defined. The strong difference between America and Europe that we saw in Figure 5 is largely a function of the divergent starting points in 1970. Figure 6 shows the relationship more accurately. 


\section{Figure 6}

Capital share trend, America and Europe, 1970-2010

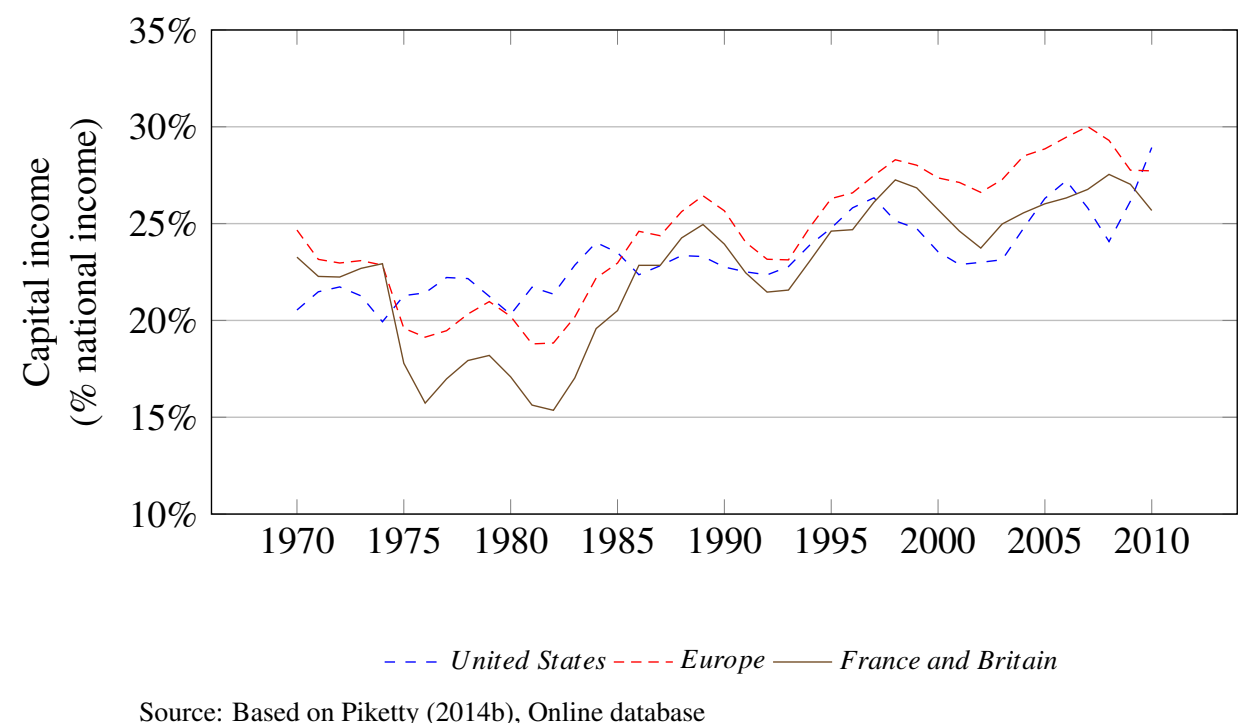

Figure 6 then matches fairly well with the wealth inequality trend in Piketty's Figure 10.6. In both cases the experience of America and north-western Europe are closely comparable. Also worth noting is that Figure 6 shows a far less dramatic rise than that seen in Piketty's Figures 5.3 and 5.4. That too fits with the nearly-flat trend in wealth inequality.

In general then the trends that Piketty presents of the economic drivers do not cohere in themselves. Reducing the analysis to a simple 'America versus northwestern Europe' comparison, we find Europe leading America in Figures 1 - 4, America leading Europe in Figure 5 and the two on par in Figure 6, but only after 1985. Only Figure 6 after 1985 correlates well with his wealth inequality trends. For Piketty himself it is the capital/income ratio (his Figures 5.3 and 5.4, my Figures $1-4$ ) that has the prime role in his argument, yet it has the least resemblance to his evidence about wealth inequality trends.

\section{Income inequality}

We turn now to individual level trends and Piketty's analysis of private income. His key evidence is presented (below) in Figure 9.8 ('Income inequality: Europe versus the United States, $1900-2010$ '), which tracks the share of the top decile in total income. 
Here 'Europe' is a composite of France, Britain, Germany and Sweden. In this presentation income inequality in Europe, as measured by the top decile share, is no greater in 2010 than it was in 1940. Since 1980 income inequality in continental Europe (France, Germany and Sweden) has been rising but not dramatically (up by about 12\%, based on Piketty's Figure 9.7). By contrast in the United States in 2010 income inequality was $40 \%$ higher than in 1970. These look like two very different pathways, with the trend in Britain occupying a middle position (up by $27 \%$ since 1980). If we are to explain this difference by reference to the economic drivers we would expect those drivers to be stronger in the United States than in continental Europe. Figure 5 above supports this expectation, though Figure 6 is much less supportive. More importantly Figures $1-4$ show the opposite: the capital/income ratio rise is far weaker in America than in continental Europe.

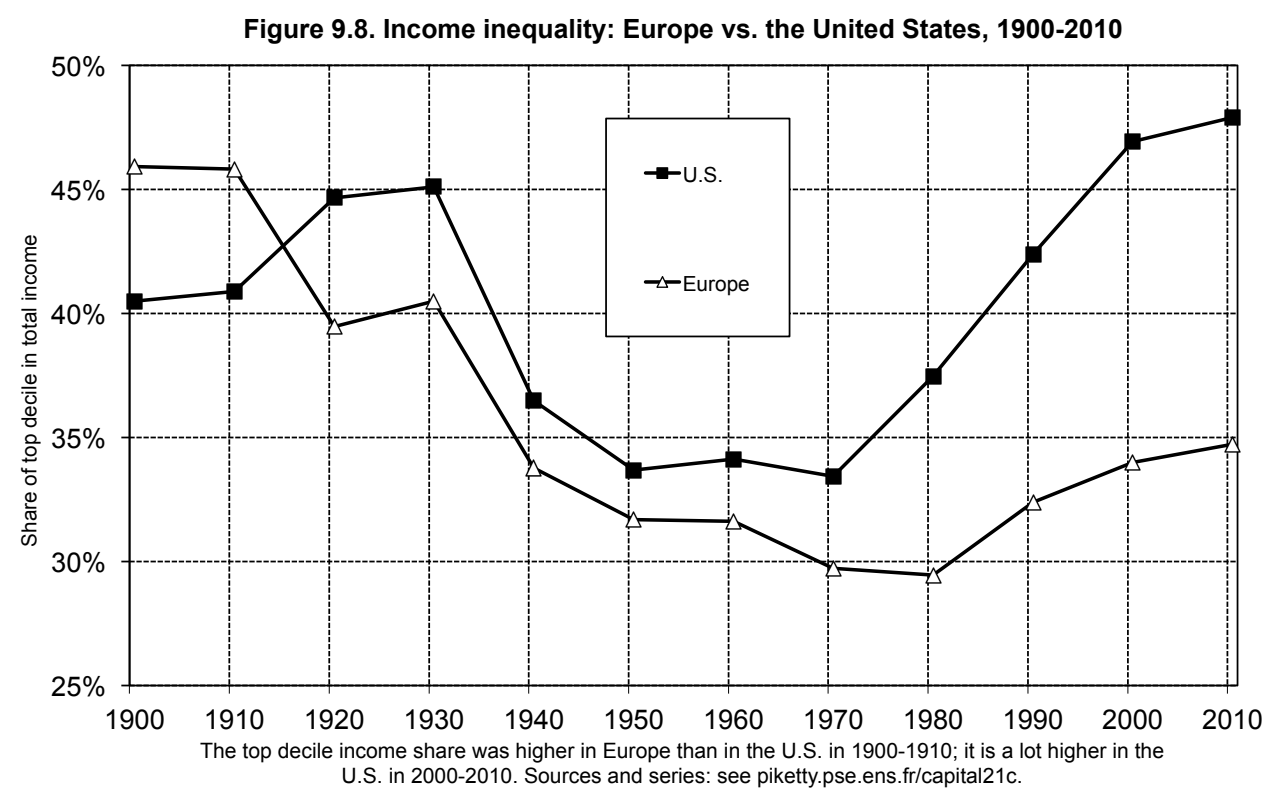

\section{Top wealth trends in ten countries}

The lack of evidence for increased wealth inequality, though not prominent in the debate about Capital in the Twenty-First Century, has not gone unnoticed (most strongly in Facchini/Couvreur 2015). Piketty has replied (Piketty 2014b) by pointing to more recent work on the American data by his colleagues Emmanuel 
Saez and Gabriel Zucman. They conclude: 'On the basis of new, annual, long-run series, we find that wealth inequality has considerably increased at the top over the last three decades. By our estimates, almost all of this increase is due to the rise of the share of wealth owned by the $0.1 \%$ richest families, from $7 \%$ in 1978 to $22 \%$ in 2012, a level comparable to that of the early twentieth century' (Saez/Zucman 2014, p. 1). Piketty's own database shows a share increase from $12 \%$ in 1970 to $15 \%$ in 2010). The corollary of this is that there is little increase in wealth inequality at the $1 \%$ level and even less at the $10 \%$ level. This trend at the $0.1 \%$ level in America is hardly very supportive of Piketty's analysis since (apart from the fact that it relates to only one country) it is on the wrong scale. The inequality-promoting trends that Piketty highlights are operating on much larger scales: in the case of income inequality, on the $10 \%$ and $1 \%$ scales, while the capital/income ratios show a doubling over the same time span that Saez and Zucman are tracking. That leaves the question of why Piketty's forces are producing so little effect. In addition we need evidence on wealth inequality from the other modern economies before we can conclude that there is a general trend across these economies. Just such a study, by Jesper Roine and Daniel Waldenström, is now available. They compare top wealth distribution trends within the top decile - that is, between the top $10 \%$ and the top $0.1 \%$ - in ten modern economies. Here our concern is with the post-1970 evidence, summarized in Table 2 (derived from Roine/Waldenström 2015, pp. 521 - 538).

Table 2

Wealth concentration trends in ten countries, 1970 to 2010

\begin{tabular}{|c|c|c|c|c|c|}
\hline & P90 - 95 & P90 - 99 & P95 - 99 & P99- 100 & P99.9- 100 \\
\hline Australia & & & & Up & \\
\hline Denmark & Up & & Flat & Flat & \\
\hline Finland & Flat & & Down & Up & Up \\
\hline France & & Flat & & Flat & Flat \\
\hline The Netherlands & & & Flat & Down & Down \\
\hline Norway & Flat & & Down & Flat & Up \\
\hline Sweden & Flat & & Flat & Flat & \\
\hline Switzerland & Flat & & Flat & Down & Flat \\
\hline United Kingdom & Flat & & Down & Flat & \\
\hline United States & Flat & & Up & $\begin{array}{l}\text { Flat (households) } \\
\text { Flat (individuals) }\end{array}$ & \\
\hline
\end{tabular}

Source: Based on Roine/Waldenström 2015, pp. 521-538. The descriptors are mine, not theirs.

Overall we have here 32 trendlines. Six are rising, six are falling and 20 are flat. There is no general trend towards rising wealth inequality across these ten cases. Piketty's Figure 10.6 is a fair representation of this general flatness. 


\section{Conclusion}

My argument has sought to make six points.

1. In Piketty's trend analysis the individual level trends in wealth inequality since 1970 show little rise in the United States or Europe. This point involves no analysis of my own; it is read straight off his own evidence. Piketty however thinks that his evidence has shown a moderate or more than moderate rise. These claims are not warranted. Even stronger claims about the risk of a deep economic divide are even less warranted by his own direct evidence.

2. His own evidence on wealth inequality shows little difference between post1970 trends in the United States and Europe, contrary to his contention that the former shows a greater rise than the latter.

3. His analysis of post-1970 capital/income ratios shows a strong general rise, roughly a doubling, but that rise is not well suited to explain the trend in wealth inequality, which by his own evidence is a very low rise. This point holds good for both of his ways of measuring the capital/income ratio, whether as private capital as a fraction of national income or as private capital as a fraction of household domestic income.

4. A closer examination of his capital/income ratios, in either of his versions, shows that the rise has been markedly greater in Europe than in America. This is at odds with the post-1970 trend in wealth inequality, which is the same in Europe and America.

5. Piketty's evidence on the post-1975 capital-labor split (which he downplays, preferring instead to focus on the capital/income ratio) seems at first to show a much stronger rise in American capital shares than in European. However this apparent difference is a function only of trends in the period 1975 to 1985; thereafter America and Europe follow a common path, rising only slightly. This suggests that the capital-labor split (unlike the capital/income ratio) is fairly well suited to serve as an explanation of the wealth inequality trend.

6. There is a mismatch between Piketty's income inequality trends and his three other trends (capital/income, capital-labor and wealth distribution). Since 1970 income inequality has been rising rapidly in America, Britain and Canada, but far less so in Europe. In none of the other trends is this the case. If rising income inequality is a strong factor in wealth distribution, we would expect wealth inequality to be rising faster in America than in Europe, but on his own evidence this is not the case. 
The most important point here is the first. Piketty has not shown that wealth inequality increases are at all substantial, even though showing this seems to be his main ambition.

The remainder of my argument involves a reverse engineering of his strategy: since wealth inequality is not rising markedly what does that tell us about the putative causes that might be operating upstream? My position can be summed up as contending that only the capital-labor split after 1985 looks like a plausible explanation of the wealth inequality trend. This contention if sound doesn't amount to a disproof of Piketty's main argument - the argument that modern economies contain strong forces tending to generate wealth inequality - but it does I think significantly weaken its force.

Part of my argument has been to focus on the comparison between America and Europe in its various permutations. One curious, though perhaps minor, result emerges from this. In Piketty's view the capital/income ratio $(\beta)$ is 'in some sense a measure of how intensely capitalistic the society in question is' (Piketty 2014a, p. 55). In both his Figures 5.3 and 5.4 the United States starts in 1970 with the highest capital/income ratio and finishes in 2010 with the equal lowest. If growth in capital shares of the economy is a sign of capitalism's evolution, then America is on this showing the least capitalist of the major modern economies. On the other hand, as his Chapter Nine and Figure 9.8 show, income inequality has grown far more strongly in America than elsewhere. I have no suggestions about how to make sense of this.

In some respects Piketty (Piketty 2014b) is modest about what his overall argument shows:

Let me make very clear that I do not believe that $r>g$ is the only force that determines the dynamics of wealth inequality. There are many other important forces that could in principle drive wealth inequality in other directions. The main message coming from my book is not that there should always be a deterministic trend toward ever rising inequality (I do not believe in this); the main message is that we need more democratic transparency about wealth dynamics, so that we are able to adjust our institutions and policies to whatever we observe.

But if his own evidence (and even moreso that of Roine/Waldenström) shows virtually no recent trend in wealth inequality, then it is hard to see how his story about $r>g$ can shed any light on wealth dynamics. Piketty sees that he cannot assert that wealth inequality is in actual fact rising strongly: that claim is never made. The most he will say, rather weakly, is that 'inequality of wealth began to rise again in 1970 - 1980' (Piketty 2014a, p. 372). But the bulk of his argument about the dynamics of wealth accumulation (in Chapters Three to Nine) suggests it should be so rising. Hence at the end of Chapter Ten all he can say is that 
wealth inequality very likely will return to past high levels if progressive taxation is weakened to allow the dynamics of capitalism to operate unimpeded. '[T]he reason why wealth today is not as unequally distributed as in the past is simply that not enough time has passed since 1945' (Piketty 2014a, p. 372).

Capital in the Twenty-First Century is perhaps best read as a warning of what might happen in future rather than as an explanation of what has actually happened since 1945. At the end of the book the author speaks of capitalism as containing 'powerful forces of divergence, which are potentially threatening to democratic societies and to the values of social justice on which they are based' (Piketty 2014a, p. 571). Piketty, we might say, is predicting trouble ahead even if things are relatively tranquil now. But since the force of this 'potential' is far from clear and is very dependent on one's background assumptions, this would seem to be a weak finale to an otherwise stirring book. Piketty's economic drivers ( $\alpha$ and $\beta$ ) and his income inequality trend have been on the rise for about 40 years plenty of time, one might think, for these to impact on the structure of the wealth distribution.

\section{Bibliography}

Facchini, F., Couvreur, S. (2015) “Inequality: The original economic sin of capitalism? An evaluation of Thomas Piketty's 'Capitalism in the Twenty-first Century' ", European Journal of Political Economy, 39, 281-287.

Krugman P. (2015) "Why we're in a new gilded age”, New York Review of Books. 8 May. http://www.nybooks. com/articles/archives/2014/may/08/thomas-piketty-new-gilded-age/

Kuznets S. (1955) "Economic growth and income inequality", American Economic Review, 45, 1-28.

Piketty T. (2014a) Capital in the Twenty-First Century, Cambridge MA: Harvard University Press.

Piketty T. (2014b) Technical appendix of the book Capital in the Twenty-First Century. Appendix to Chapter 10, "Inequality of capital ownership", Addendum: Response to FT, May 28. http://piketty.pse.ens.fr/ capital21c

Roine J., D. Waldenström (2015) "Long-run trends in the distribution of income and wealth", Atkinson, A.B., Bourguignon, F. (eds.) Handbook of Income Distribution, vol 2, North Holland, 469-592.

Saez, E., G. Zucman (2014) Wealth inequality in the United States since 1913: Evidence from capitalized income tax data, NBER Working Paper Series, Working Paper 20625. 